\title{
Adoption and Knowledge of Sheep Husbandry in Hills of Jammu \& Kashmir, India
}

\author{
Suraj Parkash $^{1^{*}}$ and Pawan Kumar Sharma ${ }^{2}$ \\ ${ }^{1}$ Krishi Vigyan Kendra, Rajouri, ${ }^{2}$ Krishi Vigyan Kendra, Kathua, Sher-e-Kashmir University \\ of Agricultural Sciences \& Technology of Jammu, J\&K, India \\ *Corresponding author
}

\section{A B S T R A C T}

Keywords

Sheep husbandry, Adoption, Knowledge, Rajouri

Article Info

Accepted:

23 April 2020

Available Online:

10 May 2020
A study was conducted to analyze the factors associated with knowledge and adoption of sheep husbandry in Rajouri district of UT of Jammu \& Kashmir. The test of significance showed that adopters had higher socio-economic status as compared to non-adopters. The test also proved that there was a significant difference between adopters and non-adopters regarding knowledge about sheep rearing and that adopters had more knowledge than non-adopters. 46 per cent adopters and 30 per cent non-adopters had high socio-economic status whereas 40 per cent adopters and 36 per cent non-adopters had medium socio-economic status. Also, 14 percent of the adopters and 34 percent of non-adopters had low socio-economic status. 90 per cent of adopters had good knowledge about sheep rearing compared to only 18 per cent in case of non-adopters. 50 per cent adopters reared sheep only to earn money, 8 percent for good quality of manure and 2 percent for meat. Among the major reasons for non-adoption of sheep husbandry were lack of space (39\%), lack of finance (33\%), lack of improved breeds (24\%) and susceptibility to diseases $(17 \%)$.

\section{Introduction}

Agriculture has assumed vital importance in our country in terms of both income and employment. Farmers however remain unemployed for 4-5 months in a year. Besides agricultural production, the sheep farming has been helping to great extent in providing employment to large section of people. Sheep farming has the additional advantage that it does not require much capital or space and does not involve great risk. Sheep is an important livestock species and has four main food security dimensions which include cash, nutrition, food with high animal reproductive rates and climate adaptability. Sheep husbandry is mainly popular among women due to their importance in fulfilling household needs, easier accessibility and control over on benefits (Waithanji et al., 2015). The management practices decide derivation of benefits from sheep, including consumption 
through ownership of the animals (Galiè et $a l ., 2015)$. In India they contribute greatly to the agrarian economy, especially in the arid/semi arid and mountainous area where crop and dairy farming are not economical. India ranks $3^{\text {rd }}$ in the world in sheep population after China and Australia whereas ranks $7^{\text {th }}$ in terms of mutton and wool production (Planning Commission, 2012). The sheep population of India has increased from 48.76 million in 1982 to 57.49 million in 1997 to 71.56 million in 2007 (Planning Commission, 2012). However, $19^{\text {th }}$ Livestock census of India recorded sheep population of 65.069 million $\left(19^{\text {th }}\right.$ Livestock Census of India, 2014). Sheep husbandry plays an important role in the livelihood of large percentage of small and marginal farmers and landless labourers. A number of rural based industries use wool and sheep skins as raw material. Sheep manure is an important source of soil fertility. A lot of infrastructure in the form of sheep breeding and production facilities, such as sheep breeding research stations was established and research technologies generated. Development programmes were also taken up in different states by setting up sheep and wool extension centres, intensive sheep development projects and large sheep breeding farms for producing exotic and superior native rams. Sheep development has also been made an integral part of the IRDP.

Adoption of innovations means application of an innovation and its continuous use (Rogers and Shoemaker, 1971). The establishment of Farm Science Centres (Krishi Vigyan Kendras) in every district aims at development of both agriculture and animal husbandry sectors. In-spite of all these efforts, the achievement has not been satisfactory in terms of expected and requisite impact on adoption of sheep husbandry. There were many studies conducted in India to find out the factors affecting the adoption of sheep husbandry and the scientific practices, as conducted by Satyanarayana and Jagadeeswary (2010); Reddy et al., (1998); Sharma and Reddy (1998) and Meena and Singh (2012).

The present study was conducted in Rajouri district of UT of Jammu and Kashmir to identify the factors behind the adoption of sheep husbandry and thus to suggest measures for boosting the adoption of sheep husbandry and better implementation of state sponsored programmes for its development.

\section{Materials and Methods}

\section{Profile of study area}

The Rajouri district of UT of Jammu and Kashmir is situated between $32^{\circ} 98^{\prime}$ and $35^{\circ}$ $52^{\prime}$ North latitude and $74^{0} 01$ ' to $74^{0} 23^{\prime}$ 'East longitude. The district touches Poonch, Pulwama, POK in the west and Jammu in the south. Rajouri District is ideally suited for sheep and goat rearing owing to its topography and agro-climatic conditions and a host of other natural endowments. About $60 \%$ of rural population is directly or indirectly benefited from Sheep Husbandry. The Small Ruminants rearing is the Prime mean of livelihood of the Nomads Gujjer, Bakerwal and Gaddi communities. The small and marginal farmers of plain belt also rear sheep and goats in whole of plain belt mainly for Mutton production sheep are being crossed with Hissar Dale, Rambi $\times$ Nali $\times$ Sonali crosses. For the migratory sheep flocks owned by the nomads' emphasis have been laid on introducing the dual type sheep which have the traits for producing the good quality wool and fair carcass quality for mutton production beside fine wool breeds. The Rambouillet and Merino crosses procured from govt. owned sheep breeding farms have been introduced in to this area. The quality Rams are provided to the sheep owners free of cost for the breeding 
purpose. At present $70 \%$ to $80 \%$ of sheep population have been brought under the ambit of cross-breeding for fine wool production and are at varying level of up gradation. The Bakerwal tribe is the main tribe which is engaged in sheep rearing activities. In Rajouri District about $12 \%$ population is comprised of Bakerwals (Nomadic tribes) and mostly rear cattle and they are herdsmen of buffaloes. They sell surplus animals and their subsidiary products and buy maize, rice and grocery from the villages for day-to-day consumption.

A list of Eighty two villages of Rajouri Block of District Rajouri was obtained from Block Development Office Rajouri. Five villages (Chatyar, Godhar, Sarnoo, Potha and Bagla) from the list were selected randomly and then from each village, list of adopters and non adopters were made. From the prepared list of adopters and non-adopters, ten adopters and ten non-adopters were selected randomly. Thus, 100 respondents from five villages were selected which includes fifty adopters and fifty non adopters of Sheep as subsidiary occupation. Information and opinions were obtained from all the respondents through personal interview with pre-structured and pre-tested schedule. Some of the important factors were listed in the schedule and respondents were asked to give reasons which led them to adopt sheep rearing. Like-wise non-adopters were asked to give reasons which prevented them from adopting sheep rearing. ' $z$ ' test and ' $t$ ' test were applied to compare the adopters and non-adopters in terms of their socio-economic status, knowledge level and reasons behind adoption of sheep rearing as subsidiary enterprise.

\section{Results and Discussion}

\section{Socio-economic status of respondents}

The socio economic status of respondents was measure with the scale used by Trivedi and Pareek (1964) with some modification. A number of sub items were taken namely; Caste, Education, Occupation, Size of family, Type of family, number of sheep, Income, Land holding, Housing, Social participation, Material possession and each sub item was given score. Then total score of each respondent was computed. The score distribution of adopters and non-adopters are given in Table 1. It can be observed that most of the adopters belong to higher socioeconomic status.

To find out relationship between adoption of sheep rearing and socio-economic status, the following null hypothesis was tested by $\mathrm{z}$ test. The scores of socio-economic status for both adopters and non-adopters were presented in Table 2.

\section{Null hypothesis $\left(\mathrm{H}_{0}\right)$}

There was no significant difference in the socio economic status of adopters and nonadopters (Table 2) and therefore the null hypothesis cannot be accepted.

Since the calculated value of $\mathrm{Z}$ is greater than the table value of $\mathrm{Z}$ (1.96). Therefore null hypothesis was rejected and research hypothesis was accepted. Therefore it may be concluded that adopters have high socioeconomic status as compare to non-adopters.

\section{Knowledge of respondents about sheep rearing as a subsidiary occupation}

The knowledge of respondents about sheep rearing was determined by a set of twelve questions. The respondents were divided into three categories namely; poor, average and good on the basis of knowledge score obtained by them and as presented in Table 3. The Table 4 indicates that majority of adopters (90\%) had good knowledge of sheep rearing, as contrast to only 18 percent in case of non-adopters which obviously had majority percentage (60) under poor knowledge category. 
To find out if there is any significant difference between adopters and non-adopters with regard to their knowledge about the sheep rearing as subsidiary occupation, the following null hypothesis $\left(\mathrm{H}_{0}\right)$ was used for testing.

\section{Null hypothesis $\left(\mathrm{H}_{0}\right)$}

There was no significant difference in the knowledge regarding sheep rearing between adopters and non-adopters.

To test the hypothesis, the knowledge score of 12 statements were arranged which are given in Table 4. The ' $t$ ' value was calculated to test the proposed hypothesis.

As the calculated value of ' $t$ ' (20.38) is greater than the table value, null hypothesis may be rejected and it may be concluded that there was a significant difference between adopters and non-adopters, with regard to their knowledge about sheep rearing. The adopters had more knowledge about sheep rearing than non-adopters, as indicated by higher average score for adopters (43.92) than the non-adopters (28.92).

\section{Factors associated with adoption of sheep rearing}

The factors associated with adoption of sheep rearing were assessed through the answers given by the respondents (adopters) to a number of questions asked to them and are presented in Table 5. The major reason behind adoption of sheep husbandry is to earn the money which could supplement the agricultural income of farmers in Rajouri district of Jammu and Kashmir. The results are in line with Beyene et al., (2018) and Etalema and Abera, 2018), who also revealed that argued that generation of cash income was the main reason for keeping small ruminants.

\section{Factors associated with rejection of sheep rearing}

The factors associated with rejection and nonadoption of sheep as subsidiary occupation was assessed by asking relevant questions to selected non-adopters, the detail of which has been presented in Table 6 .

The majority of non-adopters (78\%) did not keep sheep due to lack of space. Among other major reasons for non-adoption were lack of finance (66\%), lack of good breeds (48\%), lack of cooperation from the government (38\%), disease susceptibility (34\%), feed unavailability (22\%) and lack of time to attend sheep (26\%). Caste prejudices and nonpreference for sheep meat and milk were the other minor reasons mentioned by nonadopters.

Table.1 Comparison of socio-economic status of the respondents $(\mathrm{N}=100, \mathrm{~A}=50, \mathrm{NA}=50)$

\begin{tabular}{|l|c|c|c|}
\hline \multicolumn{1}{|c|}{ Category } & Score interval & Adopters (A) & Non-adopters (NA) \\
\hline Low & Below 20 & 7 & 17 \\
& & $(14.00)$ & $(34.00)$ \\
\hline Medium & $20-30$ & 20 & 18 \\
& & $(40.00)$ & $(36.00)$ \\
\hline High & Above 30 & 23 & 15 \\
\multicolumn{2}{|l|}{ Figures in parentheses indicate percentage } \\
\hline
\end{tabular}


Table.2 Showing socio-economic score of the respondents $(\mathrm{N}=100, \mathrm{~A}=50, \mathrm{NA}=50)$

\begin{tabular}{|l|c|c|c|c|c|}
\hline S. & \multicolumn{2}{|c|}{ Scores } & S. & \multicolumn{2}{c|}{ Scores } \\
\hline No. & Adopters & Non-adopters & No. & Adopters & Non-adopters \\
\hline $\mathbf{1}$ & 43 & 30 & 26 & 25 & 27 \\
$\mathbf{2}$ & 19 & 34 & 27 & 27 & 32 \\
$\mathbf{3}$ & 11 & 23 & 28 & 39 & 24 \\
$\mathbf{4}$ & 16 & 32 & 29 & 29 & 31 \\
$\mathbf{5}$ & 14 & 36 & 30 & 31 & 35 \\
$\mathbf{6}$ & 25 & 21 & 31 & 32 & 16 \\
$\mathbf{7}$ & 23 & 24 & 32 & 34 & 21 \\
$\mathbf{8}$ & 23 & 29 & 33 & 31 & 22 \\
$\mathbf{9}$ & 11 & 25 & 34 & 28 & 18 \\
$\mathbf{1 0}$ & 20 & 20 & 35 & 34 & 31 \\
$\mathbf{1 1}$ & 31 & 27 & 36 & 35 & 19 \\
$\mathbf{1 2}$ & 39 & 26 & 37 & 34 & 20 \\
$\mathbf{1 3}$ & 32 & 33 & 38 & 19 & 19 \\
$\mathbf{1 4}$ & 35 & 19 & 39 & 30 & 43 \\
$\mathbf{1 5}$ & 33 & 23 & 40 & 29 & 16 \\
$\mathbf{1 6}$ & 25 & 24 & 41 & 27 & 31 \\
$\mathbf{1 7}$ & 33 & 19 & 42 & 28 & 33 \\
$\mathbf{1 8}$ & 30 & 32 & 43 & 30 & 34 \\
$\mathbf{1 9}$ & 24 & 18 & 44 & 29 & 24 \\
$\mathbf{2 0}$ & 33 & 26 & 45 & 32 & 30 \\
$\mathbf{2 1}$ & 26 & 16 & 46 & 28 & 21 \\
$\mathbf{2 2}$ & 19 & 23 & 47 & 33 & 32 \\
$\mathbf{2 3}$ & 32 & 31 & 48 & 29 & 16 \\
$\mathbf{2 4}$ & 31 & 25 & 49 & 32 & 21 \\
$\mathbf{2 5}$ & 34 & 27 & 50 & 32 & 20 \\
\hline Mean $($ X) $=28.38$ and Mean $(Y)=25.58$ & & \\
Calculated value of $Z=2.15 ;$ Table value of $Z=1.96$ & \\
\hline
\end{tabular}

Table.3 Showing the knowledge score and knowledge categories of respondents

\begin{tabular}{|l|c|c|}
\hline \multicolumn{1}{|c|}{ Categories } & \multicolumn{2}{c|}{$(\mathrm{N}=100, \mathrm{~A}=50, \mathrm{NA}=50)$} \\
\cline { 2 - 3 } & Adopters & No. Respondent \\
\hline Poor (5-10) & 1 & 30 \\
& $(2.00)$ & $(60.00)$ \\
\hline Average (10-15) & 4 & 11 \\
& $(8.00)$ & $(22.00)$ \\
\hline Good (15-20) & 45 & 9 \\
& $(90.00)$ & $(18.00)$ \\
\hline
\end{tabular}


Table.4 Knowledge score of respondents $(\mathrm{N}=100, \mathrm{~A}=50, \mathrm{NA}=50)$

\begin{tabular}{|c|c|c|}
\hline Statement & Adopters & Non-adopters \\
\hline $\mathbf{1}$ & 47 & 38 \\
$\mathbf{2}$ & 43 & 38 \\
$\mathbf{3}$ & 49 & 34 \\
$\mathbf{4}$ & 43 & 20 \\
$\mathbf{5}$ & 49 & 36 \\
$\mathbf{6}$ & 47 & 32 \\
$\mathbf{7}$ & 44 & 32 \\
$\mathbf{8}$ & 47 & 26 \\
$\mathbf{9}$ & 29 & 17 \\
$\mathbf{1 0}$ & 38 & 18 \\
$\mathbf{1 1}$ & 46 & 26 \\
$\mathbf{1 2}$ & 45 & 30 \\
\hline Mean (Adopters) $=43.92$ and Mean (Non-Adopters) $=28.92$ \\
Calculated ' $t$ ' value $=20.38$ & \\
Table value of ' $t$ ' at 22 d.f. and 0.05 alpha level $=2.074$ \\
\hline
\end{tabular}

Table.5 Factors associated with adoption of sheep rearing

\begin{tabular}{|l|c|}
\hline \multicolumn{1}{|c|}{ Factors } & $\begin{array}{c}\text { No. of } \\
\text { Adopters }\end{array}$ \\
\hline To earn money & 50 \\
For meat & $(100.00)$ \\
\hline For good quality of manure & 2 \\
& $(4.00)$ \\
\hline To utilize spare time & 8 \\
& $(16.00)$ \\
\hline Any other & 2 \\
& $(4.00)$ \\
\hline
\end{tabular}

Table.6 Showing factors associated with rejection of sheep rearing

\begin{tabular}{|l|c|}
\hline \multicolumn{1}{|c|}{ Factors } & No. of non-adopters \\
\hline Susceptibility of disease & $17(34.00)$ \\
\hline Unavailability of feed & $11(22.00)$ \\
\hline Caste prejudices & $4(8.00)$ \\
\hline Lack of space for keeping sheep & $39(78.00)$ \\
\hline Lack of time to attend sheep & $13(26.00)$ \\
\hline Do not eat meat and drink milk & $2(4.00)$ \\
\hline Lack of co-operation from govt. & $19(38.00)$ \\
\hline Lack of good breeds & $24(48.00)$ \\
\hline Lack of finance & $33(66.00)$ \\
\hline
\end{tabular}


The main limitations in sheep husbandry highlighted in earlier studies were lack of artificial insemination under field conditions due to migratory and semi-migratory practices, illiteracy among sheep farmers, their prejudices and convictions and difficulties in the preservation and storage of ram semen, fodder scarcity, non-availability of required food, poor credit facility, unremunerative price, poor veterinary facility etc. (Saha et al., 1994; Rathore, 2004; Narain and Kar, 2005, Senthil and Meganathan, 2005; Singh et al., 2006).

In conclusion, there was a significant difference between the attitude of adopters and non-adopters towards sheep rearing as a subsidiary occupation. Adopters had higher level of knowledge in sheep rearing than nonadopters. The main motivational factor behind the adoption of sheep husbandry was profit whereas the limiting factor was the lack of space for rearing sheep. Sheep husbandry was as important enterprise for supplementing income of rural households and therefore steps need to be taken by government agencies to eliminate limitations in sheep husbandry. Among the adopters, scientific sheep husbandry practices should be promoted for enhancing profitability.

\section{References}

Beyene A, Alilo A, Mola M. 2018. Assessment of sheep and goat (small ruminants) production system in Esera District, of Dawro Zone, Southern Ethiopia. Journal of Advanced Dairy Research 6: 2.

Etalema S, Abera A. 2018. Small ruminant production and constraints in Misha Woreda, Hadiya Zone, Southern Ethiopia. International Journal of Livestock Production 9: 192-197.

Galiè A., Mulema A., Benard M A M, Onzere $\mathrm{S} \mathrm{N}$ and Colverson K E. 2018.
Exploring gender perceptions of resource ownership and their implications for food security among rural livestock owners in Tanzania, Ethiopia, and Nicaragua. Agriculture and Food Security, 4:2.

Kumar G S and Meganathan N. 2005. Marketing of Sheep/ Mutton. Indian Journal of Marketing 19(3): 52-60.

Meena M L, Singh D. 2012. Adoption level of sheep farming practices by the farmers in arid zone of Rajasthan. Indian Journal of Small Ruminants 18(1): 157159.

Narain P, and Kar A. 2005. Drought in Rajasthan: Impact, Coping Mechanism and Management Strategies. Central Arid Zone Research Institute, Jodhpur.

Planning Commission. 2012. Report of the working group on animal husbandry and dairying 12th five year plan (201217). Government of India, New Delhi.

Rathore J S. 2004. Drought and household coping strategies: A case of Rajasthan. Indian Journal of Agricultural Economics 59: 689-708.

Reddy G R, Rashid M A and Reddy P R. 1998. Adoption of sheep and goat husbandry practices by farmers in Gunter district of Andhra Pradesh. Journal of Research, ANGRAU 25(3): 49-53.

Rogers E M and Shoemaker F F. 1971. Communication of Innovation: A Crosscultural Approach. Second Edition. The Free Press, New York. 476p.

Saha A, Love H A and Schwart R. 1994. Adoption of emerging technologies under output uncertainty. American Journal of Agricultural Economics 76: 836-846.

Satyanarayan K and Jagadeeswary. 2010. A study on knowledge and adoption behaviour of livestock farmers. Indian Journal of Animal Research 44(2): 100106. 
Sharma G R K and Reddy K V R. 1998. Impact of training programmes on level of adoption of improved practices among sheep farmers. Mysore Journal of Agricultural Sciences 32(3): 233-235.

Singh D R, Kaur S and Sivaramane N. 2006. Migratory sheep and goat production system: the mainstay of tribal hill economy in Himachal Pradesh. Agricultural Economics Research Review 19: 387-398.

Waithanji E, Njuki J , Mburu S, Kariuki J, Njeru F. 2015. A gendered analysis of goat ownership and marketing in Meru, Kenya. Development in Practice, 25: 188-203

Wodajo H D, Gemeda B A, Kinati W, Mulem A A, Eerdewijk A V, Wieland B. 2020. Contribution of small ruminants to food security for Ethiopian smallholder farmers. Small Ruminant Research. 184: 106064. https://doi.org/10.1016/j.smallrumres.20 20.106064

\section{How to cite this article:}

Suraj Parkash and Pawan Kumar Sharma. 2020. Adoption and Knowledge of Sheep Husbandry in Hills of Jammu \& Kashmir. Int.J.Curr.Microbiol.App.Sci. 9(05): 2789-2796.

doi: https://doi.org/10.20546/ijcmas.2020.905.321 